\title{
Le Fanu's Carmilla and Freud's A Case of Hysteria (Dora): Establishing Identity in Hysteria Discourse
}

\author{
Sayaka Oki \\ Faculty of Global and Regional Studies, Doshisha University, Kyoto, Japan.
}

How to cite this paper: Sayaka Oki. (2022) Le Fanu's Carmilla and Freud's A Case of Hysteria (Dora): Establishing Identity in Hysteria Discourse. Journal of Humanities, Arts and Social Science, 6(1), 16-27.

DOI: $10.26855 /$ jhass.2022.01.002

Received: December 7, 2021

Accepted: December 30, 2021

Published: January 18, 2022

*Corresponding author: Sayaka Oki, Faculty of Global and Regional Studies, Doshisha University, Kyoto, Japan.

Email: sayaka.oki@hotmail.com

\begin{abstract}
This paper aims to analyze the queer constellation between the female narrator and vampire in Joseph Sheridan Le Fanu's novella Carmilla (1872/2010) in the context of hysteria discourse. Specifically, this paper highlights that the vampirism in Le Fanu's novella represents the unconscious and hysterical, as related to Sigmund Freud's psychoanalytical theory in A Case of Hysteria (Dora) (1905/2013). Considering that literary images of female vampires have a long tradition, this paper reviews the literary works on female protagonist vampires in chronological order. Then, Laura's pathological existence is explored in comparison with Freud's theory on hysteria. This paper's target characters, Laura, Carmilla, and Dora, are all remarkably in their adolescence and on the way to establishing their identities. Moreover, as Freud defined, dreams represent repressed wishes. In this context, Laura's unforgettable and frequent childhood dream is analyzed in the context of her queer desire, as evidenced by her openly inviting Carmilla to her schloss in Styria. Thus, this paper considers these two young women's "dual existence" as an interaction between the conscious (Laura's intellectual writing) and unconscious (Carmilla's vampiric desire). Finally, this paper discusses Laura's subject-position as the authorial narrator of the novella. Different from Freud's patient Dora, who cannot find her identity autonomously and interrupts Freud's cure, resulting in the study's fragmented ending, Laura establishes her subject independently by writing a story about her doppelganger Carmilla without Doctor Hesselius' diagnosis. Laura's emancipated position as the authorial narrator is underlined, whereby she reconstructs her fragmented reminiscence.
\end{abstract}

\section{Keywords}

Vampire Literature, Hysteria Discourse, Narrative Structure, Identity, Homosexuality

\section{Introduction}

The classical image of an insidious vampire as the main character has been established in the vampire literature genre. For instance, the undead in Bram Stoker's eternal bestseller Dracula (1897) has been adapted into many films in the $20^{\text {th }}$ Century, whereby the binary structure between Count Dracula as predator and human beings as prey (especially young women) has settled in the figurative constellation. In addition, the rational characters, such as doctors who attempt to rescue the victims, are also commonly male figures. The interplay between masculinity and femininity, intellect and emotion, predator and prey dominates the canonical vampire literature, as fundamental gendered images. According to Fiedler (1973), a postmodern literary theorist, this vampirism structure is defined in 
the Brothers Grimm's popular fairy tale Little Red Riding Hood from the Children's and Household Tales (1812) collection. The big bad wolf's cannibalistic act can correspond to the image of the vampire who can continue living by consuming human blood, the red hooded girl reflects the innocent female victim, and the huntsman has a similar function to the doctors and professors who are the only ones able to rescue the young girl from the crisis and give the story a happy ending.

This fairy tale, among others, reflects mass psychology, as it is based on folklore passed along anonymously from generation to generation before they are collected and written within an artistic work. Specifically, Little Red Riding Hood describes the psychological process that Freud defined as the oedipal phase (Bettelheim, 1976). The wolf can be seen as a metaphor of sexual pleasure, whereas the mother or the huntsman appears as the reality principle. The adolescent girl ignores her mother's instructions to not stop on the way to grandmother's house, representing the act of killing the same sex-parent, and follows the pleasure principle of the wolf. In this sense, the cannibalistic image of hunting human beings in vampire literature is also connected to sexual desire.

In his novella Carmilla (1872/2010), the fifth story of his In a Glass Darkly collection, Joseph Sheridan Le Fanu (1814-1873) thematized the emotional relationship between vampire and human, based on a fundamental construction of predator and prey. However, different from the gendered structure of male vampire and female victim, the novella is situated in a homosexual relationship between two protagonists, the female vampire Carmilla and the young woman Laura. Le Fanu's novella deals with the symptoms of nervousness and hysteria, and reflects female knowledge about marginalized homosexuality:

Nineteenth-century literature is filled with images of sexual women as perverted and unnatural, yet Carmilla, in her erotically charged dialogues with Laura, tries to convince her friend that female sexuality and homoeroticism are natural, using a Darwinian language of biological determinism to describe her passion for her friend. (Heller, 1996, 85)

Therefore, Carmilla's embodiment as a queer vampire was challenging in the heteronormative period (Yan, 2020). As the female vampire knows her own characteristics well and is quite adaptable, she symbolically changes her name in the plot to Millarca. In this context, it becomes evident that "Carmilla is a masquerader, an actress, an image linked in medical discourses with the hysteric, whom doctors distrust, because her illness may be a cover for and indeed may be caused by her sexual immorality" (Heller, 1996, 81).

As cited above, previous research emphasizes that hysteria is an important issue in Le Fanu's creation of vampirism. However, the novella has not yet been interpreted in terms of women establishing identity in the hysteria discourse. Further, it should be underlined that Freud's A Case of Hysteria (Dora) (1905/2013) published under the title Fragment of an Analysis of a Case of Hysteria in 1905 serves as a theoretical basis for analyzing the novella - both works mainly deal with the complex evolution of Laura and Dora as independent subjects. Therefore, this study is novel in its intertextual close reading of Le Fanu's novella and Freud's Dora Case. Analogous with Freud's position as an authorial narrator who wrote a pathological case study about Dora, Doctor Martin Hesselius, a German Physician, represents the position of medical correspondent who has received from his patient Laura a writing about her reminiscences and psychological depictions of a dual existence (vampirism). The prologue of Carmilla notes that Doctor Hesselius wrote a paper on this subject. In this perspective, it should be noted that not only does Carmilla show symptoms of hysteria and nervousness, but the narrator, Laura, is also diagnosed with the psychical disease whose pathological circumstances are similar to Freud's Dora. Nevertheless, one significant difference is that the novella is not constructed from Hesselius' perspective. Instead of a medical diagnosis, Laura is the one who writes the fantastic vampire literature, settling herself within the subject position. Therefore, this study particularly analyzes the meaning behind Laura's process of establishing her identity through writing as the authorial, first-person narrator.

\section{Literary Works about Female Adolescent Vampires}

The characterization of a female adolescent vampire was particularly established through Le Fanu's Gothic novella Carmilla, but this representation of protagonists appeared in the vampire literature tradition both before and after the novella. This chapter examines which aspects, within female vampire characterizations, are similar and different in the following literary works: Johann Wolfgang von Goethe's Bride of Corinth (1797), E.T.A. Hoffmann's Vampirism (1821), Sheridan Le Fanu's Carmilla, and the contemporary dramatist Moira Buffini's A Vampire Story (2008). These authors described emotional and spiritual vampires who are suffering with their undead identities as well as their subversive potential. The absolute taboo is thematized when these female vampires at- 
tempt to construct relationships with human beings. They represent and reflect both the violent image of an apathetic monstrous killer and an expressive individual who can talk about the past, as well as their feelings and familial circumstances. These spiritual vampires think, speak, write, and act from their own free will and perspectives. For example, Eleanor, a 16-year-old vampire from Buffini’s drama A Vampire Story, is depicted as an intellectual and sensitive storyteller who recounts her self-controlled life from a subject position in the biographical story. The border between life and death, romance and cannibalism, predator and prey, future and past has been thematized as a central issue in these literary works.

In the $20^{\text {th }}$ Century, the image of female vampires was transformed, especially as lesbian and bisexual vampires, into a film metaphor of vampirism in popular culture (Heller-Nicholas, 2017). Le Fanu especially contributed to this image of a homosexual vampire, with Carmilla being prominent in her beautiful, seductive appearance and self-controlled, contemplative acts. Specifically, these figurative features have influenced queer descriptions in films about lesbian and bisexual female vampires (Heller-Nicholas, 2017), as evidenced in Lambert Hiller's Dracula's Daughter (1936), Roy Ward Baker's The Vampire Lovers (1970), Harry Kümel's Daughters of Darkness (1971), Jesús Fraco's Vampyros Lesbos (1971), Tony Scott’s The Hunger (1983), and Brest Wood's The Unwanted (2014).

The oldest image of an adolescent female vampire appeared in Goethe's ballade Bride of Corinth, created in the High Classical literary period. His poem extracts source materials from the second century, namely from Phlegon of Tralleis' Das Buch der Wunder, a collection of mystery stories concerning marginal figures. Specifically, Tralleis' ghost story in which the dead young woman Phillinion returns and seeks her lover Machates undoubtedly influenced Goethe's ballade. He rewrites the motif of absolute romance between vampire and human being, whereby the sensitive, spiritual vampire bride expresses her feelings of not wanting to hurt the pagan youth for the sake of love. In this literary period, the concept of the spirit and the mental was discussed in Friedrich Schiller's artistic essay Gedanken über den Gebrauch des Gemeinen und Niedrigen in der Kunst (1973), which became a philosophical basis for considerations on the spiritual vampire (Schemme, 1986). Despite the pagan youth's passionate proposal, she modestly rejects him several times, because she is aware of the cannibalistic tragedy that will occur if she accepts him: "Drau not nigh, O Youth! A far remain! Rapture now can never smile on me” (Goethe, 1797, 269). After her numerous attempts, she finally decides to spend the night together with the pagan youth. At the end of the poem, she implores her mother to cremate the lovers for their eternal peace.

Different from the metaphorical effect of modest behavior, Hoffmann's Vampirism places more emphasis on the vampire bride Aurelie's subversive potential that is the phantastic darkness, which is represented as her violent and cannibalistic desire. The horrific, but also aesthetic story was published as the eighth part of The Serapion Brothers (1819-1821) collection during the Romanticism literary period. In contrast with his short story Sandman (1816), in which according to Freud, the Sandman character takes the symbolic meaning of the authoritarian and horrific father who castrates his son Nathanael by stealing his eyes, the mother in Vampirism falls into this authoritarian character role by forcing Aurelie to marry an abominated stranger at the age of 16 . Aurelie was still on her way to establish her identity in her adolescence period. According to her mother's persuasion, the stranger is a wealthy person and if she marries him, the whole family does not need to worry anymore about being reduced to poverty. Nevertheless, she follows her own intentions and denies her mother's persuasion. Thus, the father in Sandman, who psychologically distresses Nathanael, and the mother in Vampirism, who embarrasses Aurelie, both represent the same-sex dominant parent. The mother-daughter relationship in Vampirism can also be interpreted as the Elektra complex during Aurelie's adolescence.

In the Vampirism tale, it is obvious that both the mother and Aurelie have unconscious cannibalistic desires. After the mother's death and the daughter's marriage to Count Hyppolit, Aurelie's vampiristic character awakens. As she could not establish her own identity in her adolescence, because of her mother's overwhelming pressure, her depressive embarrassment finally turns into aggression. Aurelie begins to talk about her secret past with her mother to her husband Hyppolit, whereby it becomes obvious that the vampire bride possesses a literary flair with fluent verbal expression. As the narrator in Hoffmann's novella is Hyppolit, Aurelie's vampiric story is illustrated through his perspective. Although her conscious intellectual appearance dominates her storytelling, her infernal spirit awakens after she confesses her past. Aurelie no longer reflects emotional sensibility and feeling expressions in her words toward her husband. On the contrary, Hyppolit becomes a victim of her vampirism. In this context, the novella has the inevitable consequence of ending tragically.

These images of female vampires also influenced popular literature in the $21^{\text {st }}$ Century. Fiedler $(1973,14)$ no- 
ticed that in a time like our own, "cannibalism, especially in the form of vampirism, has become again a compulsive theme of popular literature, indeed a central feature of mass culture in general.” Similar to Hoffmann's Vampirism, Buffini also thematized the mother-daughter vampire relationship in A Vampire Story, which was adapted into Neil Jordan's film Byzantium (2012). The main characters are two female vampires: Claire, a very fashionable and bold individual who can control men's minds, and Eleanor Wythenshawe, a more sensitive vampire, who expresses her feelings despite her soullessness, symbolically emphasized in the film by her artistic talent of playing the piano. Eleanor, who is eternally 16, is the author of her vampire story. She dramatically recounts her tale in the form of a dialogue and notes that she spent 200 years with Claire. As opposed to Claire's unconscious violent desire for hunting, Eleanor's cannibalistic desire is solely fulfilled following her policy to only hunt weakened persons who are near their death. Although their characteristics are diverse, they do not want to be separated, due to their deep trust in each other. Eleanor tells her secret vampire story in front of her lover, Frank, in a drama class, because she does not want to lie about her existence for moral reasons. Understandably, this act becomes a crucial danger for both Eleanor and Claire. In this sense, Eleanor's subject-position in her vampire story also corresponds with Laura's writing as a narrator in Le Fanu's Carmilla. When describing her life to Doctor Darvell, Eleanor symbolizes the intellectual and expressive storyteller more than the unconscious vampiric desire to suck blood. Eleanor is the author of her vampire story. The following quote depicts how she writes her own story, and the extent to which she needs to repress her feelings and natural vampiric desires in her existence:

ELLA: May I have a pen and paper?

DARVELL: In due time, you shall have everything you want

ELLA: I need to finish my story

DARVELL: Of course you do

ELLA: It's about a girl. She meets a boy. He's a genius, but every bit as friendless as she. The girl has been alone for a long time. The boy tries to bring her back to life. But her past is gone; the present hurts; she has no future. She is the beetle who crawled into amber

DARVELL: What do you mean?

ELLA: I cannot die, though I know I am dead. I am hungry all the time but I cannot eat. My desires are destructive. I live off others. I am alone. I am vampire (Buffini, 2008/2016, 60-61)

\section{The Function of Dreams}

In Le Fanu's Carmilla, which was published a year before the author's death in 1873, the main subject is the homosexual relationship between two young women. As Laura is 19 at the time of her story and Carmilla serves as Laura's doppelganger figure, characterizing her dual existence, it is suspected that Carmilla is around the same age. In his literary works, Le Fanu predominantly thematized the concerns of the unconscious (Achilles, 1991). In this sense, Carmilla's vampirism represents the unconscious desire to appropriate her lover for herself and bring her into her realm of death. The scenes of this story are set in Styria, Austria, where folks' belief about the "followed death (Nachsterben)" was documented by Romuald Pramberger shortly after WW: a death is going to be follow ed by another death of a close member in the family (Weingand, 2014). As such, this predominant folk belief in Styria inevitably influenced Le Fanu's scene selections to represent Carmilla's vampirism.

Similarly, Basil Hall's Schloss Hainfeld: Or, A Winter in lower Styria (1836) also became the basis for Le Fanu's writing and scene selections (Weingand, 2014). The book documented that Hall had personal interactions with the eccentric Countess Johanna Anna Purgstall (1760-1835), who lived in schloss Heinfeld, until her death on March 23, 1835. The life of Johanna Purgstall was described in the third Chapter "The Countess", which must have contributed to creating the figurative model in Carmilla. The Countess was Scottish and married a German nobleman from the most esteemed family in Austria. After the marriage, she never returned to her native country. However, her husband died in 1811 and a few years later, his only child also died. The widow's hopeless and traumatic loneliness caused some hysterical symptoms, such as rheumatism in the right shoulder, gout, trigeminal neuralgia, nervous cough (especially at night), and anxiety (Hall, 1836). She had been confined for three whole years to her bed, on which her son had died 17 years prior. In spite of her somatic and psychical symptoms, she possessed a memory of uncommon tenacity and could tell stories perfectly by citing Schiller and Goethe, or Haydn and Mozart (Hall, 1836). She could also write and read perfectly. In this context, the novella Carmilla's connection with hysteria discourse is established based on the Countess' symptomatic depictions in schloss Hainfeld. This may reflect the possible reason why Le Fanu chose this place in Styria, Austria as the literary scene for Carmilla. 
It should be noted that Austria is also where Freud's psychoanalysis sprouted in the late $19^{\text {th }}$ Century. Accordingly, it would be interesting to determine to what extent the novella's protagonists, Laura and Carmilla, are depicted within the discourse of psychoanalysis, especially in relation to the women's disease, hysteria. Although there were cases of male hysteria in the late $19^{\text {th }}$ Century, as Freud evidenced in his paper about the male hysteria cases that he presented on October 15, 1886 at the medical society in Wien, the psychiatric diagnosis identified hysteria as a naturally occurring women's disease caused by the uterus. As the authority on hysteria studies in the late $19^{\text {th }}$ Century, Jean-Martin Charcot developed a study on hypnosis to treat hysteria. Additionally, Josef Breuer used a therapy method termed the "talking cure" or "chimney sweeping” that involved patients talking about their fragmentary reminiscence. With Freud, Breuer published the psychoanalytical work entitled Studies in Hysteria (1895), containing the case studies of about five women: Fräulein Anna O., Frau Emmy von N., Miss Lucy R., Katharina, and Fräulein Elisabeth von R. The first case explained the ailments of Bertha Pappenheim, referred to as Anna O., in which Breuer used the "cathartic method" of making patients express their reminiscences. Coauthor Freud developed Breuer's therapeutic method in his hysteria studies, which was especially used in A Case of Hysteria (Dora) (1905/2013). Freud's patient Dora (her real name was Ida Bauer) was born on November 1, 1882 in a middle-class Jewish family and visited Freud's clinic in October 1900 when she was 18. In this psychological context, it should be emphasized that both Dora and Le Fanu's narrator Laura in Carmilla (English father and Austrian mother) were in their adolescent years when they experienced their issues.

Dream analyses had a significant role in hysteria studies, as they served to reconstruct the mechanisms that are repressed in the unconscious. In this context, expressing a memory embedded in a dream is understood as a therapeutic part of the "cathartic method". Accordingly, the first chapter of A Case of Hysteria (Dora) begins with a description of the importance of dream analyses, which was additionally published in The Interpretation of Dreams (1900). It is important to note that hysteria analyses were also conducted in connection with these dream interpretations.

In my book I mentioned the way in which I came to the problems of dreams. I came upon it while I was trying to cure psychoneuroses by a particular process of psychotherapy, during which my patients told me, among other incidents in the life of their minds, about dreams that seemed to require to be placed somewhere in the long-drawn-out connection between symptoms of illness and pathogenic ideas. I discovered at the time how, without further instruction, we must translate the language of dreams into a means of expression comprehensible in the terms we normally use to express thoughts. (Freud, 1905/2013, 11)

The significance of integrating patients' dreams during the process of psychotherapy for treating hysteria intends to show how dream interpretations come into play during the psychoanalytical treatment. In fact, Dora's two dreams were cited and interpreted in the second and third chapters. Before the psychotherapy began, she already had symptoms stemming from her childhood: breathlessness when she was eight years old and migraine like headaches with attacks of nervous coughing when she was around 12. These symptoms came back frequently as she grew up and when she visited Freud's clinic at the age of 18, she suffered from coughing as well as a complete loss of her voice caused by nervous straining.

At the beginning of the first dream analysis, which addressed a house fire, Dora mentioned that she had the exact same dream several times before. As such, Freud discusses the significant function of periodically recurrent dreams. It is common that people forget their dreams after waking up, but some dreams have been anchored in the memory and return several times in exactly the same way, as Dora had experienced. Parallel to the frequent attacks of the aforementioned symptoms she had since her childhood, the dream also occasionally returned to her conscious. That kind of dream should especially be integrated in the context of analysis, because it is influenced by the reconstruction of a patient's fragmented reminiscences.

A normal dream stands, as it were, on two feet, one of which derives from the actual nature of the occasion for it, the other on a childhood event with serious consequences. The dream creates a link between the childhood experience and the present experience, it seeks to turn the present into a model of the dreamer's distant past. The wish that creates the dream always comes from childhood; it wants to bring childhood back to life again and again, to correct the present by reference to the childhood model. (Freud, 1905/2013, 60)

Similarly, the novella Carmilla begins with a description of Laura's dream, which was "one of the very earliest 
incidents of [her] life” (Le Fanu, 1872/2010, 235). She is assumed to be no more than six years old at the first occurrence. Laura's frightening dream constituted an image of a young lady who came to her when she felt lonely at night. Laura's close relationships in the schloss were with her father, Madame Perrodon, and Mademoiselle De Lafontaine. Unfortunately, Laura's mother died during her infancy. In the dream, the lady was very kind to her at first, came into her bed, and lay with her. As Laura fell asleep relieved, she suddenly felt two needles poke into her breast and woke up astonished. The image of Carmilla was initially instilled into her memory and her conscious with this dream. The dream itself, which Laura remembered since she was six years old, "creates a link between the childhood experience and the present experience" (Freud, 1905/2013, 60). Due to her fearfulness, a servant tended to her every night until she was about 14 years old. The dream about a vampire determined Laura's reminiscence of her childhood and as she reached the age of 19, she in fact experienced the existence of her doppelganger. She could not forget the dream, which originated from her childhood, as it was so deeply anchored in her mind.

For a long time, she became nervous and frightened, because of this dream, and her state reflected her first psychiatric symptoms. Although a doctor was called in and gave her medicine every second day, her anxiety did not truly disappear. As she believed that the young lady existed in reality and indeed visited her at night, it became more than a mere dream. In this context, the difference between reality and dreams cannot be strictly distinguished in Laura's mind. As medicine or physical treatments could not cure her state, it is possible to argue that the symptoms arose from her psychological problems related to loneliness. Since her infancy, her wish to live with her mother and to be surrounded by close familiar persons was repressed into her unconscious, because this wish could not be realized in her situation, living in the lonely schloss in Styria. The early death of her mother created a depressive deficiency in Laura's psyche that was converted into a desire to obtain a mother-daughter relationship, depicted metaphorically as a homosexual relationship. Accordingly, Freud noted that every dream is a form of a wish:

I explained in my book that every dream was a wish represented as if fulfilled, the representation was a disguise if the wish was a repressed one, belonging to the unconscious and [...], only an unconscious wish or one bordering on the unconscious has the power to create a dream. I believe I would have found general agreement with this more certain if I had confined myself to saying that every dream has a sense that can be found by a certain method of interpretation. [...] Instead, I put forward a general claim confining the meaning of dreams to a single form of thought, the representation of wishes [...]. (Freud, 1905/2013, 57)

In addition, Laura's solitude is radicalized with the following incident: General Spielsdorf's niece and ward, Mademoiselle Rheinfeldt, could not visit the schloss since she died from her illness. As evidenced in the chapter "Bereaved," her illness was brought about by becoming a victim of Millarca, who sucked her blood. Laura's father depicted Rheinfeldt as a very charming girl, which caused Laura to daydream about this potential new acquaintance for many weeks, but her wish to meet her could not be fulfilled. The death of two important female characters, her mother and Rheinfeldt, formed Laura's central problem, reflecting a peculiar female sensitivity and nervousness. Carmilla first enters the story when Laura's expectations of having a relationship expanded and is settled as an alternative target of Laura's wish, substituting the positions of her mother, sister, and particularly, lover. Apparently, the dream was considered a nightmare that bothered Laura for a long time, but the existence of Carmilla in the dream attracted her. When Carmilla was beside her, she felt "a kind of pleased wonder" and was "immediately delightfully soothed" (Le Fanu, 1872/2010, 235). Thus, the dream is a representation of Laura's wish for females in her life who are kind to her and stay with her, metaphorically reflected in the gestalt of Carmilla, who has an analogical function of a grand passion. As it is Laura who welcomed Carmilla into her schloss in Styria with her hospitality (Green, 2017), the moment of bloodsucking can be interpreted as a description of her unconscious sexual desire.

As Freud describes in A Case of Hysteria, Dora's first dream about a house fire corresponds to her resolution to get away from the family house, because her sexual danger "recurs every night until she has carried out that resolution, and reappears year later as soon as there is an occasion to take an analogous resolution" (Freud, 1905/2013, 72). Similar to this situation, Laura could not forget the dream about a young lady in her childhood, she could not sleep alone without a servant in the nursery until she was about 14 , and the dream returned to her conscious again when she met Carmilla.

I saw the very face which had visited me in my childhood at night, which remained so fixed in my mem- 
ory, and on which I had for so many years so often ruminated with horror, when no one suspected of what I was thinking. It was pretty, even beautiful; and when I first beheld it, wore the same melancholy expression. [...] 'How wonderful!' she exclaimed. 'Twelve years ago, I saw your face in a dream, and it has haunted me ever since.' 'Wonderful indeed!' I repeated, overcoming with an effort the horror that had for a time suspended my utterances. 'Twelve years ago, in vision or reality, I certainly saw you. I could not forget your face. It has remained before my eyes ever since.' (Le Fanu, 1872/2010, 247-248)

The description symbolizes Carmilla's function as Laura's doppelganger. After Carmilla recovered from her shock, as a result of a carriage accident, they first met in the schloss where they reminisced about two exactly corresponding dreams of each other. Laura was enthusiastic when she noticed that Carmilla understood her when she recounted her dream. Thus, mutual feelings arose between them, which the description of their dreams induced symbolically. The following passage suggests that Laura's wish, represented in her dream, came true:

Now the truth is, I felt rather unaccountably towards the beautiful stranger. I did feel, as she said, 'drawn towards her', but there was also something of repulsion. In this ambiguous feeling, however, the sense of attraction immensely prevailed. She interested and won me; she was so beautiful and so indescribably engaging. (Le Fanu, 1872/2010, 249)

At this moment, Laura and Carmilla are referring to their reciprocal enthusiasm. The dual existence is also suggested when the novella notes that Laura and Carmilla are descendants from the same family, the Karnsteins. This particularly becomes evident when they look at the renovated portraits that Laura's mother brought to Styria from her old Hungarian family. One of these portraits depicted Mircalla, Countess Karnstein, painted in 1698 A.D., who was the absolute likeness of Carmilla. In that respect, their genealogical as well as characteristic similarities are marked on the one hand, but on the other hand, the fundamental cannibalistic structure, in which the dominant (Carmilla) is absorbing the recessive (Laura), is created gradually in the course of the story.

Le Fanu's novella constructs a vampire story in the phantastic way, as a result of Laura not being released from her symptomatic nervousness, despite the recognition of her repressed desire being represented as a wish in her dream. On the contrary, her pathological state goes into a serious direction. Since that moment, when Laura and Carmilla met in the schloss, Laura had frequent perturbing dreams at night, instead of a pleasant sleep. This state symbolizes that the two different categories of dreams and hysterical symptoms are linked through their expression. Laura was suffering from "lassitude", "languor", and "melancholy", while Carmilla’s "paroxysms of languid adoration” became more frequent (Le Fanu, 1872/2010, 269-270). At the same time, Laura's impressions of her dreams were getting stronger:

Certain vague and strange sensations visited me in my sleep. The prevailing one was of that pleasant, peculiar cold thrill which we feel in bathing, when we move against the current of a river. This was soon accompanied by dreams that seemed interminable, and were so vague that I could never recollect their scenery and persons, or any one connected portion of their action. But they left an awful impression, and a sense of exhaustion, as if I had passed through a long period of great mental exertion and danger. (Le Fa$\mathrm{nu}, 1872 / 2010,270$ )

The duplicate production of hysterical symptoms and frequent dreams shows that the latter serve as an output for the pathological repression in Laura's mind. The reason why she develops these symptoms simultaneously relates to the appearance of her doppelganger and her dual existence. In other words, Laura's symptoms are both psychological and somatic. Freud theoretically explains this pathological function of dreams: "Dreaming is one of the ways whereby psychical material can reach the conscious mind although, because its content puts up lively resistance, it has been barred from consciousness, repressed, and thus has become pathogenic" (Freud, 1905/2013, 11).

Some of the typical hysterical symptoms arise around the throat, namely breathlessness, coughing, and aphonia, which Dora also experienced. In the sexual context, Freud interprets Dora's emergence of aphonia as "the expression of her affection for a temporarily absent beloved” (Freud, 1905/2013, 34). Accordingly, the symptom lasted about three to six weeks, representing the same period during which Herr K. was absent. Thus, the symptoms occurred when Herr K. was away and Dora was healthy when he came back. The bloodsucking imagery, depicted through Carmilla, also demonstrates homosexual as well as pathological aspects. The victim and patient, Rheinfeldt and Laura, had a similar appalling dream, seeing the shape of Carmilla (or Millarca) walking round the foot of their 
bed from side to side, feeling like a "flow of an icy stream against her breast" (Le Fanu, 1872/2010, 292). In addition to the symptoms of breathlessness, coughing, and aphonia, Rheinfeldt and Laura also felt a very sharp pain "a little below the throat” during their dreams, evidently caused by Carmilla sucking their blood (Le Fanu, 1872/2010, 292). Therefore, the description of dreaming is linked to somatic symptoms in the novella, especially in the connection to hysteria studies.

\section{Vampirism and Homosexuality}

As a dream is only created by "an unconscious wish or one bordering on the unconscious" (Freud, 1905/2013, 57), the relationship between Laura and Carmilla can be interpreted as one based on homosexual affection. While Bram Stoker created a cruel, canonical image of the vampire Dracula, the vampire genre has a tendency to include a sympathetic male vampire as the protagonist. The latter is especially remarkable in popular culture and literature, as seen with Angel in the TV-series Buffy the Vampire Slayer (1997-2003) or Edward Cullen in the Twilight Saga (2005-2010). These works focus on the romance that occurs between a male vampire and a young woman, which is framed by a crisis of unconscious cannibalistic desire. The romance between vampire and human being is also thematized in Carmilla, but homosexuality is the primary subject, representing one of the first literary depictions of vampiric homosexuality.

The romance had already started when Laura and Carmilla met in the schloss. Laura was particularly impressed that Carmilla's gestalt was exactly the same as she had dreamed about when she was six years old. Although she was scared and disgusted by Carmilla's two needles, she became paradoxically aware of her absolutely charm: "She was certainly the most beautiful creature I had ever seen, and the unpleasant remembrance of the face presented in my early dream, had lost the effect of the first unexpected recognition" (Le Fanu, 1872/2010, 250). Carmilla's passionate declarations of her adoration for Laura happened frequently, after which an enthusiastic physical intimacy followed: "And when she had spoken such a rhapsody, she would press me more closely in her trembling embrace, and her lips in soft kisses gently glow upon my cheek” (Le Fanu, 1872/2010, 252). As these kinds of confessions are repeated several times, their sympathy gradually turns into affection.

The psychoanalytical story of Dora mentions that such a homosexual tendency is typically acknowledged in adolescence. Specifically, this tendency can be perceived in the very close and long-lasting relationship between Frau K. and Dora: "When Dora stayed with the Ks., she shared Frau K.'s bedroom and her husband had to sleep elsewhere. [...] there was nothing that they did not discuss" (Freud, 1905/2013, 51). Their ages were very different, as Frau K. was married and Dora was only about 14 when she began to be familiar with the Ks. Thus, their situation is not exactly the same as Laura and Carmilla's double existence. However, Freud explains that queer desire is normally observed, especially in puberty, even if it is subordinated in the psychological mechanism of heteronormativity.

It has long been known, and often pointed out, that in boys and girls who have reached puberty clear signs of attraction towards their own sex are normally observed. A schoolgirl's enthusiastic friendship for another, with vows, kisses, promises of corresponding for ever, and all the sensitivity of jealousy, is the usual precursor of her first, more intense attachment to a man. [...] we shall also expect to find a stronger disposition to homosexuality in the nature of a neurotic. (Freud, 1905/2013, 50-51)

Carmilla's bloodsucking is linked to her existential problem, as she could live as a charming vampire without aging for over 150 years. One of the significant characteristics of vampirism is that a vampire's vehemence should be emphasized as a hunting process resembling "the passion of love" for particular persons (Le Fanu, 1872/2010, 304). Carmilla's mysterious infatuation for Laura emerges in her repeated confessions of love before Laura suffers from her symptoms and has a feeling of strange melancholy (Le Fanu, 1872/2010, 252, 253, 262, 264). At first, Laura disliked Carmilla's agitations, but with each repetition, she got used to it and eventually accepted the recurrences. As Laura did not notice that her illness and paroxysms were caused by Carmilla's vampirism, she was simply absorbed in her beauty. As seen in the chapter "Descending," despite that Laura dreamed about Carmilla for the last time in her white nightdress, bathed from her chin to her feet in one great stain of blood, she does not believe that Carmilla is an assassin, as her mother had warned her in the dream. This suggests that Laura's deepest trust in Carmilla evokes the stable and long lasting effects of their homosexual relationship. When Laura awoke from her last dream and finally found Carmilla in reality, she ran to her "in ecstasy of joy; [she] kissed and embraced her again and again" (Le Fanu, 1872/2010, 273). It can be interpreted that Laura sacrificed herself through this unconscious impulse. Overall, this act symbolizes Laura's repressed homoerotic passion and altruistic love for 
Carmilla.

\section{The Narrator's Subject-Position: Laura's Identity as a Storyteller}

Le Fanu's literary collection of five stories, published under In a Glass Darkly (1872), is constructed as medical and psychological cases for which Dr. Martin Hesselius, the German physician, had drawn up his own scientific remarks. As clarified in each prologue of these five stories, his anonymous medical secretary, who worked for him for nearly 20 years, is considered as the editor of this work. In Dr. Hesselius' immense collection of papers, his secretary found about 230 cases, as explained in the prologue of The Familiar, and out of those, he selected the particular cases for the five stories in the compilation. Every case is mostly in the form of a letter or essay that Dr. Hesselius received from the patients or wrote himself.

All these stories, except Carmilla, namely Green Tea (1871), The Familiar (1847), Mr. Justice Harbottle (1872), and The Room in the Dragon Volant (1872), are constructed from the perspective of the male narrator. Nevertheless, the absolute mystical power of a demonic existence is represented in every story and the protagonists are all suffering from certain symptoms as well as illusions. Additionally, these stories tragically end with death: Mr. Jennings in Green Tee commits suicide, Mr. Barton in The Familiar dies because of insanity, and Mr. Harbottle in Mr. Justice Harbottle was found hanging by his neck. Although Richard Beckett in The Room in the Dragon Volant does not die, his afterlife was ultimately formed by the shock and horrible impressions. By examining these endings, it becomes apparent that the mysterious spirits, which represent the unconscious in the psychoanalytical context, are uncontrollable and more dominant than the human ratio. Not only do they seize human bodies and souls, causing an array of symptoms, but they ultimately also kill the protagonists. Showers (2014) pointed out that Swedish philosopher Emanuel Swedenborg's mystical religious doctrine Heaven and Hell (1758) peeked Le Fanu's interest in the existence of "evil spirits who communicate with hell" and "non-human entities that seek to ruin the immortal soul of man" (24).

Accordingly, the unconscious often appears visually "in the shape of the beast (fera)" (Le Fanu, 1872/2010, 11), as seen in the black monkey in Green Tea and the fine old owl in The Familiar. Even in Carmilla, the unconscious agitation of the vampire emerges in the shape of a monstrous cat. For example, Laura describes the vampirism she experienced one night as a cat that "appeared to [her] about four or five feet long for it measured fully the length of the hearthrug as it passed over it; and it continued to-ing and fro-ing with the lithe, sinister restlessness of a beast in a cage" (Le Fanu, 1872/2010, 266). As this passage reveals, these uncontrollable evil spirits are metaphorically compared to animal wildness. In other words, the opposition between the conscious and the unconscious is literarily categorized into human and beast forms. In addition, as the unconscious does not have a verbal expression, the metaphorical beasts only appear visually, but they do not speak a word, let alone express their feelings. Therefore, this symbolizes the non-verbal aspect of unconscious desire.

Carmilla is the last medical case among these five mysterious stories. It is the only tale in the collection that deals with women's lives and psychical problems. The female narrator, the protagonist Laura, does not die at the end. Rather, it can be interpreted that she is on the way to physical and mental recovery. In fact, the experienced story is written from the perspective of the female narrator to reconstruct her trauma that is repressed in the unconscious: the early deaths of her mother and Rheinfeldt both left her in a state of deep loneliness. The story can also be understood as the cathartic method process during which Laura's writing, as the narrator, is confronted with the non-verbal unconscious. The binary structure between the verbal conscious (Laura as the narrator) and the non-verbal unconscious (Carmilla's vampirism in the shape of a beast) is fundamentally settled in the novella. Similar to the other stories in the collection, Dr. Hesselius wrote a note about Laura's case, but his anonymous secretary, the editor, did not select his medical analysis for publication in the volume, because the story was simply meant to entertain the "laity" without providing any specific medical knowledge. Indeed, this can be considered as one of the reasons for making Laura the narrator, considering that she communicates her narrative "with such conscientious particularity” (Le Fanu, 1872/2010, 232), but Laura’s subject position as the narrator can also represent the psychoanalytical process of reconstructing reminiscences by writing down her experiences. In this way, Laura is able to establish her identity by explaining her story.

In hysteria discourse, it is important to establish the identity of the patients by reconstructing their fragmented reminiscences. Thus, Laura's symptoms should disappear as a result of the long lasting therapy, employing the cathartic method, for which Laura writes the story about her doppelganger Carmilla. In other words, this concerns the process of bringing the repressed unconscious into the conscious. Freud's psychological fragment in A Case of 
Hysteria can be analyzed as a woman's incomplete establishment of her identity under the conditions of oedipal-familial situations (Schuller, 1990a). Instead of finding the subject-position, Dora's description is interpreted according to her sexual desire, sometimes in the position of her mother and at other times, in the position of her father's lover, in addition to the position of Herr and Frau K's lover. However, Dora cannot find her own identity under these circumstances and in this sense, for herself, she is nothing (Schuller, 1990a). Dora's fragmented description of her memory is written and analyzed from the male perspective, in other words, the first-person authorial narrator. Dora interrupted the therapeutic process of "talking cure" exactly at that moment when "[Freud] had every expectation of bringing the analysis to a happy conclusion [...] She seemed to be moved, said goodbye in the most charming way, wishing me every happiness in the New Year, left—and did not come back" (Freud, 1905/2013, 93).

On the contrary, the narrator in Carmilla is the protagonist Laura, who shows somatic hysterical symptoms and wrote the lesbian vampire story, representing her reflections on her doppelganger, as a psychological treatment in her feministic emancipation. She knows exactly what happened to her at the end when she expresses Carmilla's execution, as well as the great friendship between her father, General Spielsdorf, and the expert Baron Vordenburg, and understands the meaning of vampirism, as evidenced by her citing Baron's knowledge about historical vampire books: "Magia Posthuma," "Phlegon de Mirabilibus," "Augustinus de cura pro Mortuis," and "Philosophicae et Christianae Cogitationes de Vampiris" (Le Fanu, 1872/2010, 304). In this sense, it is possible to interpret Laura as a patient who consults a doctor on the one hand and as a rational individual on the other hand, because she is aware of every occurrence in detail and is able to write about her experiences from the subject-position in a rational manner. This aspect of Laura's storytelling is also linked to Heller's (1996) argument that Le Fanu's “vampire tale makes a similar metonymic association between female homoeroticism and female knowing, both processes that make women independent of male control” (89).

Furthermore, the aesthetic depiction of queer desire in vampirism, as an act of the "new woman," represents the counterpart of the Victorian women's "domestic angel” ideal, because neither Carmilla nor Laura participate in the incarnation of perfect housewife, submissive spouse, or caring mother (Zerovnik, 2014). Laura's effectiveness as a narrator is especially underlined in her intelligence and strong mind, as she is able to objectively manage and explain the details of her emotional affects. Thus, it is possible to assume that Laura recovered from her vampirism induced illness at the end of the story and that her psychoanalytical therapy of writing her reminiscence ended successful. Despite that Doctor Hesselius wrote a paper on Laura's case, which aroused the interest of both academics and his medical secretary, he gave Laura the opportunity to write about her entire story without any interventions. Therefore, besides his authority in this context, Doctor Hesselius holds the cooperative position of Laura's observer. In the conclusion, it is written that she still sometimes hears Carmilla's light steps at the drawing room door, even after her execution. As such, the vampire lives eternally in her mind (Green, 2017). However, at the end, Laura's tour in Italy with her father, which lasted for more than a year, symbolizes her healthy condition devoid of any symptoms (in connotation with the southern sunshine). As the narrator, she noted being afraid of reconstructing the horrific story that she experienced with Carmilla, but through this conscious process of establishing her own identity by writing, she could finally be relieved from the pathological cruel dream.

I write all this you suppose with composure. But far from it; I cannot think of it without agitation. Nothing but your earnest desire so repeatedly expressed, could have induced me to sit down to a task that has unstrung my nerves for months to come, and reinduced a shadow of the unspeakable horror which years after my deliverance continued to make my days and nights dreadful, and solitude insupportably terrific. (Le Fanu, 1872/2010, 303)

\section{Conclusion}

Literary works about female adolescent vampire as protagonists have a long tradition, from Goethe's ballade Bride of Corinth and Hoffmann's novella Vampirism to Buffini's contemporary drama A Vampire Story. This paper focused on female adolescent vampires in chronological order to examine the role of the two female protagonists in Le Fanu's Carmilla. It intended to explore how the image of the female adolescent vampires has been transmitted and compare the similarities or differences. One of the common characteristics of these vampires is their sensitive and occasionally uncontrollable and passionate expression of their romantic experiences with human beings in their lifetime. These vampires are able to talk about their feelings, including their past experiences. Thus, in this context, they do not merely symbolize the nonverbal unconscious desire, but they are aware of their difficult, lonely existence and behave intellectually. Goethe’s vampire bride and Hoffmann's Aurelie explain their existence and past 
orally, whereas Buffini's Eleanor appears as the author of her written vampire story. Similarly, Le Fanu's Carmilla is also a young female vampire of similar age to Laura, about 19 years old. Laura is also the author of her story about the doppelganger Carmilla. Through this analysis, the literary constellation indicates that their independent position has been sought through verbal expression by considering their own stories.

This paper analyzed Laura's pathological experiences with Carmilla's vampirism from the perspective of the hysteria discourse, whereby the idea of women's establishment of their identity was seen in a new light with Freud's A Case of Hysteria (Dora). Freud's work was used as a theoretical basis to devise the interpretation. Hence, this intertextual interpretation of these two works in terms of women establishing identity is a contribution to the genre of vampire literature. Remarkably, Dora was also around the same age, 18 years old, when she visited Freud's clinic. In this context, adolescence is seen as a significant period during which the main characters aim to establish their identities. This paper interpreted Laura's expression as the psychological and therapeutic process of bringing her repressed queer desire into her conscious awareness. Laura's recurrent dream from her childhood had the function of confirming an unconscious wish, showing her loneliness as well as her expectations and longing for Carmilla's arrival. Her wish was realized when she invited the vampire to her schloss. This development of their intimate friendship was analyzed in the context of homosexuality. Similar to the other stories in In a Glass Darkly, Carmilla's evil spirit appears in shape of a monstrous cat when her unconscious desire breaks out. The wordless beast symbolically represents the non-verbal dynamic region of the human psyche. On the opposite side of the spectrum, Laura's act of writing corresponds with the conscious, when she appears as the narrator of the story and verbally expresses her trauma to reconstruct her fragmented reminiscences. The somatic and psychical symptoms, metonymically caused by Carmilla's vampirism, disappeared when Laura's subject-position as the narrator was established through her storytelling.

\section{References}

Achilles, Jochen (1991). Sheridan Le Fanu und die schauerromantische Tradition [Sheridan Le Fanu and the Gothic Tradition] (pp. 80-139). Tübingen: Gunter Narr.

Baker, Roy Ward. (1970). The Vampire Lovers. UK: 91min.

Bettelheim, Bruno. (1976). The Uses of Enchantment. Meaning and Importance of Fairy Tales. New York: Raines \& Reines.

Breuer, Josef/Freud, Sigmund. (2001). Studies on Hysteria (1893-1895). In James Strachey (Ed.), The Standard Edition of the Complete Psychological Works of Sigmund Freud, Volume II. London: Vintage. (Original work published 1895)

Buffini, Moira. (2016). A Vampire Story. London: Samuel French. (Original work published 2008)

Cott, Jonathan/Fiedler, Leslie (Eds.) (1973). Beyond the Looking Glass, Extraordinary Works of Fairy Tale \& Fantasy (pp. 11-20). New York: Stonehill Publishing Company.

Ellenberger, Henri F. (1993a). Freud's Lecture on Masculine Hysteria: A Critical Study. In Mark S. Micale (Ed.) Beyond the Unconscious. Essays of Henri F. Ellenberger in the History of Psychiatry (pp. 119-135). Princeton: Princeton University Press. (Original work published 1886)

Ellenberger, Henri F. (1993b). The Story of “Anna O.”: A Critical Review with New Data. In Mark S. Micale (Ed.), Beyond the Unconscious. Essays of Henri F. Ellenberger in the History of Psychiatry (pp. 254-272). Princeton: Princeton University Press. (Original work published 1972)

Endres, Johannes. (2020). Vampires and the Orient in Goethe’s “Die Braut von Corinth” In The German Quarterly 93.2 (pp. 204-220). Hoboken: John Wiley \& Sons.

Fiedler, Leslie. (1972). Cross the Border-Close the Gap (pp. 61-85). New York: Stein \& Day.

Franco, Jesus. (1971). Vampyros Lesbos. Spain/Germany: 98min.

Freud, Sigmund. (2013). A Case of Hysteria. Oxford: Oxford University Press. (Original work published 1905 under the title Fragment of an Analysis of a Case of Hysteria)

Goethe, Johann Wolfgang. (2000). Die Braut von Korinth [The Bride of Corinth]. In Erich Trunz (Ed.), Johann Wolfgang von Goethe Werke. Hamburger Ausgabe, Bd. 1. Gedichte und Epien (pp. 268-273). Munich: Deutscher Taschenbuch Verlag. (Original work published 1797) 
Green, Stephanie. (2017). Time and the Vampire: The Idea of the Past in Carmilla and Dracula. In David Baker, Stephanie Green, Agnieszka Stasiewicz-Bieńkowska (Eds.), Hospitality, Rape and Consent in Vampire Popular Culture. Letting the Wrong One In (pp. 89-106). Cham: Palgrave MacMillan.

Haining, Peter. (1995). The Vampire Omnibus. London: Orion.

Hall, Basil. (2017). Schloss Hainfeld: Or, a Winter in Lower Styria. Miami: HardPress. (Original work published 1836)

Heller, Tamar. (1996). The Vampire in the House. Hysteria, Female Sexuality, and Female Knowledge in Le Fanu's "Carmilla" (1872). In Barbara Leah Harman, Susan Meyer (Eds.), The New Nineteenth Century. Feminist Readings of Underread Victorian Fiction (pp. 77-95). New York/London: Garland Publishing.

Heller-Nicholas, Alexandra. (2017). Secuctive Kindness: Power, Space and “Lesbian” Vampires. In David Baker, Stephanie Green, Agnieszka Stasiewicz-Bieńkowska (Eds.), Hospitality, Rape and Consent in Vampire Popular Culture. Letting the Wrong One In (pp. 201-218). Cham: Palgrave MacMillan.

Hoffmann, E. T. A. (2020). Vampirismus [Vampirism]. In Wulf Segebrecht, Ursula Segebrecht (Eds.), E. T. A. Hoffmann, Die Serapions-Brüder, Volume 3. Aufl. (pp. 1119-1134). Frankfurt: Deutscher Klassiker Verlag. (Original work published 1821)

Jordan, Neil. (2012). Byzantium. Ireland/UK/US: 118 min.

Le Fanu, Joseph Sheridan. (2010). Carmilla. In In a Glass Darkly (pp. 232-306). Oxford: Benediction Classics. (Original work published 1872)

Phlegon, von Tralleis and Brodersen, Kai. (Eds.) (2002). Das Buch der Wunder, und Zeugnisse seiner Wirkungsgeschichte [The Book of Marvels] (pp. 19-46). Darmstadt: Wissenschaftliche Buchgesellschaft.

Schemme, Wolfgang. (1986). Goethe: Die Braut von Korinth. Von der literarischen Dignität des Vampirs [Goethe: The Bride of Corinth. On the Vampire's Literary Dignity]. In Theodor Lewandowski (Ed.), Wirkendes Wort. Deutsche Sprache in Forschung und Lehre 36 (pp. 335-346). Düsseldorf: Schwann-Bagel.

Schiller, Friedrich. (1980). Gedanken über den Gebrauch des Gemeinen und Niedrigen in der Kunst [Thoughts on the Use of the Meanness and the Low in Art]. (1793). In Ludwig Bellermann (Ed.), Schillers Werke 7 (pp. 223-230). Leipzig: Bibliographishces Institut.

Schröder, E./Scherer, Kristina/Möllering, Niklas/Weber, Charlotte. (2013). "Der Sandmann” von E.T.A. Hoffmann. Erzählstrukturen des Wahnsinns und des Unheimlichen ["The Sandman" by E.T.A. Hoffmann. Narrative Structures of the Madness and the Uncanny]. Norderstedt: GRIN Verlag.

Schuller, Marianne. (1990a). Literatur und Psychoanalyse. Zum Fall der hysterischen Krankengeschichte bei Sigmund Freud [Literature and Psychoanalysis. On the Case of Sigmund Freud's Hysterical, Medical History]. In Marianne Schuller (Ed.), Im Unterschied (pp. 67-80). Frankfurt: Neue Kritik.

Schuller, Marianne. (1990b). Hysterie als Artefaktum. Zum literarischen und visuellen Archiv der Hysterie um 1900 [Hysteria as Artifact. On the Literary and Visual Archive of Hysteria around 1900]. In Marianne Schuller (Ed.) Im Unterschied (pp. 81-94). Frankfurt: Neue Kritik.

Showers, Brian J. (2014). The Life and Literature of Joseph Sheridan Le Fanu. In Annette Rainer, Christina Töpfer, Martina Zerovnik (Eds.), Carmilla, der Vampir und wir (pp. 19-24). Vienna: Passagen.

Swedenborg, Emanuel. (1909). Heaven and Hell. London: J M Dent \& Sons. New York: E. P. Dutton \& Co. (Original work published 1758)

Weingand, Hans-Peter. (2014). Den leisen Schritt Carmillas... Wie die Vampire in die Steiermark kamen [The soft Step of Carmilla... How the Vampires Came to Styria]. In Annette Rainer, Christina Töpfer, Martina Zerovnik (Eds.) Carmilla, der Vampir und wir (pp. 27-36). Vienna: Passagen.

Yan, Rae X. (2020). "Artful Courtship”, “Cruel Love”, and the Language of Consent in Carmilla. In Stacey Floyd, Melissa Purdue (Eds.), http://www.ncgsjournal.com/issue163/yan.html, Ninetheenth Century Gender Studies, ISSUE 16. 3.

Zerovnik, Martina. (2014). Zwischen Vampir und Vamp: Auf der Suche nach der "Neuen Frau" in Carmilla, Dracula, Twilight \& Co. [Between Vampire and Vamp: In Search of the "New Woman" in Carmilla, Dracula, Twilight \& Co]. In Annette Rainer, Christina Töpfer, Martina Zerovnik (Eds.), Carmilla, der Vampir und wir (pp. 91-98). Vienna: Passagen. 